\title{
John Rawls, Barack Obama, and the Pluralist Political Consensus
}

PAUL SCHUMAKER

\begin{abstract}
To counter partisan polarization, political theorists like John Rawls and political leaders like Barack Obama have sought to locate and express consensual elements of American culture that can appeal to or at least be accepted by people having political, religious, moral, and philosophical differences. While orthodox pluralism previously recognized the need for a normative consensus to regulate political struggles, a new principled pluralism expands on the contents of the American consensus by proposing many political principles and philosophical assumptions that are articulated at an intermediate level of abstraction, that express the emerging (though not always present) common sensibilities of most Americans, and that can be used to justify political policies and practices.
\end{abstract}

American political culture has been depicted as having had broad, perhaps consensual, support for various liberal, republican, capitalist, democratic, religious, and ascriptive ideals, though public support for such elements of our culture has often been seen as increasing or decreasing over time and sometimes periodic or cyclical (see, e.g., Hartz 1955; McClosky and Zaller 1984; Sandel 1996; Smith 1997; Huntington 2004; Putnam and Campbell 2010). But most current commentary and analyses of American politics emphasize our "culture war" (see, e.g., Jacoby 2014; Pew Research Center for the People and Press 2014). Liberal Democrats and conservative Republicans are portrayed as being in deep conflict over what are and what should be our governing ideals. In this portrait, whatever consensus was previously thought to be part of American culture has declined, if not vanished altogether.

Paul Schumaker is professor of political science, University of Kansas, 1541 Lilac Lane, Lawrence, KS 66044 (schu@ku.edu).

I am grateful to Lynn Burlingham, Luke Campbell, Will Delehanty, Erik Hurtt, Rex Martin, David Siemers, Robert Taggart, and various anonymous reviewers for their helpful suggestions in response to earlier drafts of this paper.

American Political Thought: A Journal of Ideas, Institutions, and Culture, vol. 5 (Fall 2016).

2161-1580/2016/0504-0004\$10.00. @ 2016 by The Jack Miller Center. All rights reserved. 
Among political philosophers and theorists, however, there are claims that political communities like the United States are best characterized as having and needing both conflicting and consensual political values and orientations. John Rawls $(2005,140)$ claimed that citizens of pluralist societies "have two views, a comprehensive and a political view, and that their overall view can be divided into two parts, suitably related." First, people hold "incompatible yet reasonable comprehensive doctrines," such as various religious creeds and moralities like utilitarianism and Kantian liberalism $(99,134)$. The irreconcilability of such comprehensive doctrines means that any of them could guide our politics "only by the oppressive use of state power" (37). Thus, a second "freestanding political view" that is acceptable to people having otherwise irreconcilable moral orientations is needed to have and sustain political stability (12). As described below, the contents of this political view were characterized by Rawls as "an overlapping consensus" on such matters as basic individual rights, constitutional arrangements, social structures, and distributive principles. In short, Rawls depicted the political culture of a pluralist society like America as containing both conflicting comprehensive religious, moral, and philosophical doctrines and a consensual public philosophy. People in stable pluralist societies simultaneously hold both views in such a way that political conflict is minimized or at least manageable.

William Connolly has also claimed that democratic citizens can have and should have two views-what he calls a bicameral orientation:

There is, first, the faith, doctrine, creed, ideology, or philosophy (I do not distinguish sharply between these) that you adopt as an engaged partisan. Marxism, say. Or a branch of Christianity. Or a particular vision of science. Or Hinduism, Islam, Orthodox Judaism, Kantianism, Rawlsianism, neoconservatism, or pragmatism. There is, second, the engrained sense that you should exercise presumptive receptivity toward others when drawing that faith, creed, or philosophy into the public realm. You love your creed; you seldom leave it entirely in the closet when you enter politics. But you appreciate how it appears opaque and profoundly contestable to many who do not participate in it. $(2005,4)$

For political theorists, Connolly's emphasis on comprehensive partisan ideological doctrines is an obvious and important supplement to Rawls's focus on our religious, moral, and philosophical differences. But it is Connolly's second orientation affirming "a decent respect for the persistent diversity of the human condition" that most resembles Rawls's "freestanding political view" and produces civility and stability. 
Connolly has developed a "new pluralism" that draws on an earlier pluralist recognition of the need for an "underlying normative consensus that regulates conflicts among groups because it is the intersubjective product of society as a whole," but he has radicalized this pluralism by insisting that it contains normative ideals that are more critical, inclusive, and egalitarian than earlier pluralist formulations (Campbell and Schoolman 2008, 4-11). By emphasizing that our cultural consensus contains normative ideals that on critical reflection we ought to embrace, Connolly opens the door to conceiving Rawls's overlapping consensus broadly - to include not just those ideas that we do hold but also those ideals we ought to and potentially can hold. According to Connolly $(2005,5)$, the ideals of pluralism appeal to most Americans, but dogmatic and aggressive campaigns by powerful agents, such as those who participated in McCarthyism in the 1950s, can "overturn preliminary dispositions in favor of pluralism," prompting concern "that such campaigns are becoming hyperactive today."

Recent neglect of any consensual public philosophy is surprising, because it has been given strong voice by President Barack Obama. In his philosophical audition for the presidency, Audacity of Hope, Obama claimed that despite increasing partisan conflict, "at the core of the American experience are a set of ideals that continue to stir our collective conscience; a common set of values that bind us together despite our differences; a running thread of hope that makes our improbable experiment in democracy work" $(2006,8)$. Indeed, both in Audacity and throughout his career, Obama's bicameral orientation-his pluralist as well as his liberal commitments—was and has been plainly evident.

Obama provides an excellent opportunity to understand how politicians, especially presidents, can give voice to America's consensual political ideals. As David Siemers (2009, xii-xiii) points out, Obama has "rummaged through political philosophy, discarding most of it as impractical, but [has found] value in certain key ideas, thinkers, and concepts," especially those congruent with "widely shared cultural norms." Beyond Audacity, we now have access to many speeches given during his two successful presidential campaigns and his first 80 months in office and to his policy stances; these provide a rich basis for examining Obama's bicameral orientations. ${ }^{1}$

My main goal in this article is to provide a broad view of the American political consensus. I suggest that beneath the divisive partisan ideologies that now characterize our politics there lies an often hidden set of political princi-

1. Many of Obama's more memorable speeches parallel the ideas he provided in Audacity. For ease of accessing Obama's public philosophy, I usually reference Audacity rather than his speeches, though I sometimes provide footnotes to the speeches where these ideas are expanded on or repeated. 
ples and philosophical assumptions that I call principled pluralism. I provide an expanded version of what pluralists have seen as the underlying normative consensus that has broad appeal to most Americans. My account of principled pluralism supposes that the consensual aspects of American culture cannot be adequately understood by finding widespread support for such abstract values as freedom, equality, economic security, social order, morality, individualism, and patriotism; after all, even if most Americans do hold these values to some degree, they define and rank them differently along predictable lines of religious, partisan, and ideological division (Jacoby 2014, 758-69). To understand principled pluralism, it is important to go beyond locating commitments to such common values; its ideals must be presented in greater specificity in the form of political principles and philosophical assumptions that provide widely accepted answers to the enduring issues of politics. My account also supposes that the principles and assumptions of pluralism become clarified by juxtaposing them to more partisan views-in this case, Obama's liberalism. ${ }^{2}$

My second goal is to situate principled pluralism within Rawls's political thought. Because Rawls's overlapping consensus has become the primary conceptual tool used by contemporary political theorists for locating our consensual ideals and recognizing their critical role in advancing political legitimacy and stability, it is important to see how principled pluralism contributes to the Rawlsian tradition.

My third goal is to suggest that Obama provides evidence that principled pluralism is more than an abstract political theory; it has worked its way into practical politics. Because Obama has often expressed and appeared to be guided by the norms of principled pluralism, I argue that his pluralism has sometimes competed with his liberalism and thus explains his timid embrace of liberal goals during his presidency. This argument challenges the view of many commentators and scholars that Obama's liberal principles often are trumped by his "postpartisanship." For example, Milkis et al. (2012) argue that Obama balances his Democratic partisanship and his liberal principles with a willingness to work collaboratively with congressional Republicans. Like most analyses offered by political scientists, this characterization has the virtue of realism, of emphasizing the conflicting institutional, electoral, and political pressures that Obama has faced. However, it ignores Obama's idealism and the role that political principles often play in the activities of political leaders (Schumaker and Kelly 2012).

2. In an earlier text, I have described the main ideals of contemporary liberalism and major contributors to this ideology (Schumaker 2008). There I also used a version of the convergence method (as discussed below) to provide a preliminary overview of principled pluralism. 
Obama has emphasized abstract ideals throughout his political career. A focus on the tensions and conflicts among Obama's ideals might well serve as a useful correction to the very real tensions arising from conflicting interests and institutional pressures that are stressed by post-partisan analyses.

My fourth goal is to clarify the role of philosophical assumptions in political thought. Beyond providing a fairly comprehensive conception of philosophical assumptions, I suggest that understanding the philosophical assumptions of alternative theories helps differentiate one from another. I suggest that Obama's philosophical assumptions help explain his greater allegiance to pluralism than liberalism. I hope that better articulations of the philosophical assumptions of pluralism will help people moderate their partisan views and see the attractions of pluralism.

In section 1, I introduce principled pluralism and its relationship to Rawls's overlapping consensus.

In section 2, I discuss some of the political principles of pluralism. I first consider Obama's commitments to toleration, individual rights, constitutionalism, and a broad array of social structures. I then suggest that Obama has distributive principles that reflect the "weaker" or "thinner" pluralist ideas that Rawls adopted in Political Liberalism, but that he has also articulated justice principles that are attuned to the "stronger" or "thicker" liberal egalitarian principles stressed by Rawls in $A$ Theory of Justice. ${ }^{3}$ His speeches suggest that he believes that Rawls's principles in A Theory of Justice, at least in moderated form, should be part of the American consensus and that there may be a path to their being so in the future. But I leave unresolved here the question whether Obama is more personally committed to weaker pluralist or stronger liberal justice principles. A consideration of his deeper philosophical assumptions is needed to discover Obama's most basic public philosophy.

Because Rawls was careful to make his overlapping consensus independent of (or "freestanding" from) conflicting and controversial philosophical ideas, his (and other's) discussions of the contents of that consensus have failed to consider whether there can be rational and/or intuitive agreement on philosophical assumptions that are the basis of and help justify the political principles of pluralism as discussed in section 2. I argue in section 3 that this deficiency in Rawlsian thought can be rectified by considering how Obama has

3. A Theory of Justice was originally published in 1971, though all citations to it here come from the revised edition published in 1999. It can be interpreted as expressing Rawls's more partisan outlook, while the subsequently published Political Liberalism expresses his more pluralistic political views. Political Liberalism was originally published in 1993, but I reference the 2005 edition, which contains a new part 4 clarifying his views. 
expressed and held philosophical assumptions that reveal a broader pluralist consensus than provided by Rawls. These suggest Obama's greater commitment to pluralism than to partisan liberalism.

\section{PRINCIPLED PLURALISM}

Pluralism is widely discussed as a feature of American political culture but is understood in various ways.

Sociologists think of pluralism as a condition of diverse identities. While Obama applauds America's multicultural pluralism and indeed embodies it in his own person, pluralist ideals are not just about appreciating racial, ethnic, and other such differences; they are more complex, abstract, and intellectual.

Moral philosophers tend to think of pluralism as a condition in which many ideals and values compete for people's allegiances. While Obama recognizes the existence of moral pluralism, he believes that there exists in American political culture more consensus on meaningful ideals than is usually acknowledged; on matters of moral values, "we are becoming more, not less, alike" (Obama 2006, 51). But principled pluralism runs deeper than merely acknowledging and/or de-emphasizing moral differences.

Political commentators often suggest that vulgar pluralists too readily abandon their moral and partisan principles and values to bend to oppositional forces. While pluralism no doubt involves compromises, merely "splitting the difference" can fail to provide political stability. For example, Henry Clay's "Great Compromise of 1850" inflamed rather than calmed the conflicting passions that led to the Civil War (Troy 2012, 47). And Bill Clinton's "triangulation"-proposing policy solutions "between the old positions of the two parties, yet above them as well"-was often regarded as "waffling" and "spineless centrism" (22844). Perhaps Obama is a vulgar pluralist who bends too easily to the opposition, but the argument here is that he is a principled pluralist who has sought to find common ground for policy compromises in principles that are, or ought to be, acceptable to partisan opponents.

Political scientists normally think of pluralism as a theory of American politics developed by Robert Dahl $(1961,1967)$ and his associates that approached paradigmatic status a half century ago. This orthodox pluralism suggested that political issues are democratically resolved when power is widely distributed among many interests in society. Such dispersion of power was thought to bring about policy compromises that approximate the public interest and justiceproducing outcomes that benefit most people and that distributed benefits and burdens fairly. Orthodox pluralism did not long survive as the leading paradigm of American political science, as some critics, such as William Domhoff (1978), contested its ability to provide an accurate account of the distribution 
of power and privilege in America, and other critics, such as Theodore Lowi (1979), doubted that pluralistic power struggles could produce effective and stable politics.

Principled pluralism—having roots that Avigail Eisenberg (1995) has traced to the beginning of the twentieth century-began to be reconstructed about 30 years ago as an alternative to orthodox (power-based) pluralism. Michael Walzer (1983) argued that sheer applications of political power, no matter how dispersed, are tyrannical; to be legitimate, political decisions should be resolved through the application of justice principles. But there are many reasonable principles of justice, and there are many reasonable principles focusing on broad political goals other than distributive justice (freedom, security, economic wellbeing, etc.) that can be brought to bear on political issues.

Principled pluralism is a public philosophy that maintains that participants in politics should bring whatever principles they hold to each concrete political issue that a community faces. Each issue should then be resolved in a manner that reflects those principles that are deemed through open and reasonable deliberation to be most relevant to the issue and that are most broadly shared in the political community (Schumaker 1991). Rather than reflecting the distribution of power brought to bear on behalf of various interests, political outcomes should (and can) reflect the common and emerging moral and political understandings of most people in a polity. To be supported and considered legitimate, decisions should be justified as reflecting appropriate principles that are accessible and acceptable to participants in decision-making and to the broader public affected by these decisions. As concrete issues arise, the challenge is to find the particular principles that accomplish this task.

Principles exist at various levels of abstraction, from the relatively "thick" to the relatively "thin." Ideologues strongly hold thick principles and apply them broadly and dogmatically over a wide array of political issues. Thick ideological principles conceive political ideals in specific ways, as when the egalitarian left claims that justice requires that government distribute social goods more equally (Rawls 1999b), and when the libertarian right claims that free markets should distribute income and wealth unequally on the basis of fair processes of acquisition and exchange (Nozick 1974). Those who hold thick principles often disparage considerations that undermine their positions. These are the sort of principles that are stressed by today's ideological partisans and give the impression of a hopelessly divided Congress and country.

In contrast, thin political principles are minimal and bland. People need no ideology or deep philosophy to seek justice in the face of unfair treatment, the public interest when special interests prevail, and democracy when oligarchs dominate the political process. Who can be against justice, the public interest, and democracy? Thin principles have universal appeal because they are so 
vague that they seem consistent with all partisan views, but their very vagueness makes them inoperable as principled reasons that can justify one policy position over others.

The principles of pluralism are intermediate to such thick and thin principles. They are not so thick as to be hostile to competing values and considerations. They are not so thin as to be without meaning and practical guidance. They may not be universal, but they comprise the moral, social, and political concerns of most reasonable people within a political community.

Equal opportunity is a leading example of a pluralist justice principle that is widely shared in America today. Even as there remain gaps between the norm of equal opportunity and practices that depart from that norm, few reject the general principle. Of course, equal opportunity can mean various things and require various remedies to such gaps, but broad acceptance of the basic principle has facilitated passage of much equal rights legislation and led to far more equal opportunity than existed a half century ago. Drawing on the terminology of Rawls (1999b, 57-70), we might say that during the 1960s, a "natural" (or formal) conception of equal opportunity stressed "careers open to talents" without regard to race, ethnicity, gender, and so on. During the 1970s, a "liberal" conception of equal opportunity stressed that justice also required providing compensation for those with undeserved social disadvantages, such as being raised in crime-infested neighborhoods having inferior schools. A "democratic" interpretation of equal opportunity also emerged that sought to compensate those with undeserved natural (or genetic) disadvantages. People holding competing ideologies no doubt emphasize such alternative thicker conceptions of equal opportunity, but their agreement on the thinner but still meaningful and robust conception of equal opportunity has enabled high levels of consensus on particular issues. When racial discrimination in employment, education, and housing was at issue during the 1960 s, those committed to liberal and democratic equal opportunity could be satisfied by policy decisions, such as the Civil Rights Acts of 1964 and 1968, that sought (mere) formal equal opportunity. When improving education for children with disabilities was at issue in the 1970s and 1980s, those with democratic conceptions of equal opportunity could argue that such legislation as the Education for All Handicapped Children Act of 1975 could extend and deepen commitments to equal opportunity. In short, pluralist public philosophy seeks to maximize political agreement by employing principles-like equal opportunity—that are intermediate in abstraction, more meaningful than vague values as policy guides, and shared by those having ideological or partisan differences. Obama often invokes the idea of equal opportunity, but he argues that the methods of enhancing such opportunity change with contextual conditions, that such new forces as globalization and the increasing concentration of wealth require us to rethink the 
ways that opportunities for all citizens can be extended. But Obama makes clear that we should understand equal opportunity as something that is inadequately delivered by free markets: "we've depended on governmental action to open up opportunity" (Obama 2006, 150).

The challenge for pluralists is to locate a comprehensive set of such principles at a level of abstraction that is intermediate to the thick principles of ideologues and bland thin principles. Such principles should reflect the common and emerging understandings of most people in a political community. Such principles should be accessible to people having competing stronger but reasonable principles drawn from competing ideologies and thus can be acknowledged as being met even when their strong principles are not embodied in particular political decisions.

In Political Liberalism, Rawls made a major contribution to principled pluralism when he claimed that effective and stable politics in pluralist societies (where citizens have the autonomy to develop, revise, and pursue their own conception of the good life) require "an overlapping consensus" on some general, abstract, and relatively thin but still robust political ideas. He did not specify the contents of this consensus in detail, but Rawls did claim, "Its breadth goes beyond political principles instituting democratic procedures to include principles covering the basic structure as a whole; hence its principles also establish certain substantive rights such as liberty of conscience and freedom of thought, as well as fair equal opportunity and principles covering certain essential needs" $(2005,164)$.

The new generation of pluralist political theorists has been less interested in clarifying and elaborating the contents of Rawls's overlapping consensus than in the important matters of including previously excluded voices in political deliberations and employing public reason (Schlosberg 2006). Still, there has been some work addressing the contents of Rawls's overlapping consensus.

To describe a "liberal consensus" - a term used to refer to cultural beliefs in a liberal pluralist society rather than to indicate the predominant views of liberal partisans-George Klosko (2000, vii) suggests that Rawls was insufficiently attentive to empirical research about the actual beliefs of the American public. Drawing from public opinion surveys and the conclusions drawn from research on such data by (mostly) political scientists, Klosko argues that Rawls failed to recognize the extensive intolerance, denial of important rights, resistance to social justice, and preference for market justice that exist among the American public. ${ }^{4}$ According to Klosko, the most important con-

4. Klosko points out that in a pluralist society, consensus does not require unanimity, as there will always be those who hold views that most citizens regard as extreme and perhaps "unreasonable" $(2000,42-80)$. There will also be those whose general acceptance of plural- 
sensus in American politics is narrow and focuses on democratic procedures $(146-49) .^{5}$

Recently, Rex Martin (2014, 288-91) has argued that the primary role of the overlapping consensus is to provide a broad framework for public political justification. Two such roles can be differentiated.

First, the contents of the overlapping consensus can and should be used to justify specific practices, policies, and programs. What a political regime does should be justified by the principles contained within the overlapping consensus. To the extent that such justifications are provided by the officials of the regime and accepted by most citizens, the ideals of deliberative democracy are approached (Gutmann and Thompson 2004, 3-7).

Second, perhaps the contents of the overlapping consensus should be justified. But the problem here is that Rawls suggested that there are no ethical justifications for it (other than the thin liberal beliefs that society ought to be a cooperative arrangement and each person in it should be provided equal respect). Thus, nonphilosophical methods must be developed to identify its contents. One method is "convergence": the contents of the irreconcilable reasonable comprehensive doctrines held within the society can be examined to locate any ideas on which there is overlap or commonality among the otherwise competing doctrines. This is the method recommended by Klosko (2000, 186207), and Rawls's early presentations of the overlapping doctrine can be read as supporting this method, which would clearly lead to its contents being highly restricted. Martin suggests that this method is mistaken: the basis of the overlapping consensus is "not so much that various comprehensive doctrines (understood as 'isms') converge ...; rather it is that the considerable bulk of citizens,

ist ideas is trumped by their partisan views, moral convictions, and fears about particular applications of pluralist ideals. When trying to discern broad acceptance of principles from the results of survey research, some researchers have used $75 \%$ support for a principle as sufficient to be regarded as "consensual," but various ways of framing survey questions can influence responses in ways that preclude any hard-and-fast rules for inferring public consensus from particular polls. Given such problems, I do not report polling data in this article. Nevertheless, most polls indicate wide (though hardly unanimous) support for the principles I suggest as being part of pluralist public philosophy.

5. Klosko's work is a major contribution, but three limitations can be suggested. Perhaps he overemphasizes existing attitudes as revealed in empirical research, as the overlapping consensus can be regarded as a normative conception that articulates the beliefs that could be and ought to be accepted to achieve stability in a pluralist society. Perhaps Klosko's list of consensual principles is too narrow, as there may be other types of principles than those dealing with political rights, democratic procedures, and just distributions that can be important to combating increasing polarization and achieving stability. And perhaps Klosko (like Rawls) is insufficiently attentive to the possibility that the American consensus includes philosophical assumptions that are widely embraced, or at least not much challenged, in American society. 
coming from diverse perspectives, do" $(2014,289)$. Martin points out that Rawls always sought to find consensual ideas in "the fundamental ideas we seem to share through the public political culture" (Rawls 2005, 150).

The term overlapping consensus would seem to imply the convergence method, but if the better method of determining the contents of our consensus is to examine the political culture and identify widely accepted public norms, the term underlying consensus, which has long been used and sought by pluralists, seems better to capture this approach. Politicians with pluralist sensibilities, like Obama, use this approach when they appeal to common moral and political understandings that most people could and would accept upon due reflection, even if they sometimes express political ideas that are inconsistent with these underling norms. To the extent that the public becomes more aware of these norms and supports politicians and policies consistent with these norms, the contents of the underlying consensus become expanded and easier to identify by scholars committed to the development of principled pluralism. Rawls (2005, 462-66) ultimately supported such "a wide view of public political culture" as the method needed to conceive the contents of the consensual ideals of liberal societies like America.

Martha Nussbaum (2011, 89-93) has also interpreted Rawls's overlapping consensus. She suggests that her "capabilities approach" aspires to be a cosmopolitan version of Rawls's nation-based overlapping consensus, or at least those elements of that consensus that deal with citizen and human rights. ${ }^{6}$ But perhaps her most important insight is that Rawls did not envision the overlapping consensus as a fixed set of widely held ideas, because widespread support for what ought to be consensual principles may not yet be present. According to Nussbaum, Rawls only requires that there be "a plausible path" to broad endorsement of the principles that are part of the overlapping consensus (90-91).

Although the open, evolving, contextual, and tentative nature of consensual values in a pluralist society precludes any definitive specification of Rawls's overlapping (or pluralism's underlying) consensus, this article is concerned with providing an account of it that is both broader than has thus far been attempted and sensitive to the subsequent analyses of it by Klosko, Martin, and Nussbaum.

6. In contrast to Nussbaum, Rawls (1999a) hesitated to regard the consensual ideas of a liberal pluralist society as having global applicability. While Rawls thought that the contents of the overlapping consensus applied to liberal nations, my concern is only with the consensus within contemporary American society. Thus, the contents of principled pluralism should be regarded as less broadly applicable than that sought by Rawls, and far less broadly applicable than the global consensus sought by Nussbaum. 


\section{THE POLITICAL PRINCIPLES OF PLURALISM}

\subsection{TOLERANCE}

Rawls's idea of an overlapping consensus can be interpreted as an extension of the liberal principle of political toleration (Klosko 2000, 6). Historically, liberals have argued that political stability requires religious toleration (of different beliefs about the sacred and divine, as argued by John Locke), moral acceptance (of different beliefs about the good life, as argued by John Stuart Mill), and philosophical broad-mindedness (about different priorities among values, as suggested by William James). Rawls, like many liberals and pluralists before him, stressed that a well-ordered and stable society requires its members to "put up with" people whose religious, moral, and philosophical views differ from their own; they adopt a "live and let live" attitude toward others, at least as long as others are reasonable and don't undermine social stability (Klosko 2000, 20, 43). While Rawls gave little attention to tolerating partisan political differences (or racial, ethnic, or sexual differences), other liberals and pluralists have emphasized these forms of toleration, and there is little doubt that Rawls shared such concerns.

Obama has often given voice to such tolerance, such as in his chapters in Audacity on faith and race. But there is another conception of tolerance where Obama has been more pluralistic than some liberals. In his initial presentation of Political Liberalism, Rawls emphasized that in public life people should adopt "public reason." They should refrain from bringing arguments from various comprehensive doctrines into political deliberations; by doing so, they fulfill their political (if not their legal) duty to make their arguments accessible to others who do not share their comprehensive doctrine (Rawls 2005, 21618). Such a liberalism is intolerant of justifications brought to bear on political issues that are rooted in particular comprehensive doctrines. While liberals may put up with people making such arguments, such views should not be accepted or included in the reasons used to justify decisions to the public. Such justifications do not treat with equal respect those not subscribing to them.

In his "Call for Renewal" address given on June 28, 2006, Obama spoke of a pluralist conception of tolerance that is more receptive to employing arguments drawn from comprehensive doctrines and that reflects Rawls's more inclusive notion of political reason as developed in subsequent editions of $\mathrm{PO}_{\mathrm{O}}$ litical Liberalism. Beyond adopting liberal and pluralist ideals about not "imposing our beliefs on one another" and not disrespecting religious values, Obama (2006, 212-19) proclaimed that "ignoring religion deprives liberals from effectively addressing issues in moral terms," that "secularists are wrong when they ask believers to leave their religion at the door before entering into 
the public square," and that "to say that men and women should not inject their 'personal' morality into public policy debates is a practical absurdity." Obama's toleration of incorporating into public discourse ideas drawn from various comprehensive doctrines, as long as they are "subject to argument and amendable to reason," expresses a wider conception of toleration that is central both to democratic principles and to the practices of American political culture than is liberal suppression of justifications that do not meet the strictures of public reason as expressed initially by Rawls. Such toleration by Obama is also consistent with the views of those political theorists who reject a "hegemonic mode of discourse" that limits political arguments to those consistent with a narrow conception of "public reason" (Wolin 1996, 102).

\subsection{RIGHTS}

Rawls emphasized that citizens must be guaranteed extensive equal rights, including freedom of thought and conscience, security against violations of their lives and personal property, due process in the legal system, and freedom of political participation and opposition. Such rights sometimes conflict, and thus some provisions for limiting even basic rights are required (Sniderman et al. 1996), though such limitations have to be equally applied to all. When such conflicts arise, partisans normally take opposing positions on which rights should be limited and which should be extended.

Obama has taken a liberal position on limiting gun rights, drawing on pluralist sensibilities that unlimited access to guns threatens other rights such as protection of lives. Obama has remarked that he believes that "the Second Amendment guarantees an individual right to bear arms. But to better protect our children and our communities from tragic mass shootings ... there are common-sense steps we can take right now." ${ }^{7}$ Still, the very modest policies and proposals he has supported in this area indicate his pluralist orientations and unwillingness to push too hard against the perceived legitimacy of the gun culture that is so prevalent in America, as well as partisan resistance to his proposed restrictions.

One option for dealing with moral differences on particular rights is to take a partisan position and try to offer convincing justifications that make that position more consensual. Obama has backed a liberal position about LGBTQ rights. Although he awaited a greater public consensus before doing so, his subsequent endorsement of gay marriage is consistent with the ideals of both liberals and pluralists that rights must be equally available to all. Obama's

7. This quote can be found at www.whitehouse.gov/issues/preventing-gun-violence. 
voice arguably contributed to the rapid changes occurring in American culture on the issue of gay rights, changes that the Supreme Court could not ignore when it upheld the right to gay marriage in its landmark ruling in Obergefell $v$. Hodges on June 26, 2015.

A second option for dealing with partisan and moral differences is to avoid issues where there are obvious conflicts among basic rights. While Obama voted for a religious freedom restoration act while serving in the Illinois Senate in 1998, that bill was thought to protect religious rights against governmental interference, and its conflict with other basic rights was not yet apparent. However, when Indiana moved similar legislation in March 2015, the conflict between religious rights and gay rights was clear. Probably out of a pluralist orientation to minimize conflict, Obama has yet to speak on the matterinstead leaving it to White House aides to argue that the religious rights provided by such legislation should not extend to the right to discriminate against LGBTQs. But, of course, such issue avoidance can be seen as mere timidity, an example of vulgar pluralism.

A third and better pluralist approach for dealing with conflicting rights is to seek policies that recognize the importance of each but draw acceptable limits on them. This approach by Obama is illustrated on the issue of privacy rights and security rights in the wake of Edward Snowden's revelations about the surveillance activities of the National Security Agency (NSA). Regardless of ideology, most Americans want both protection of their privacy and security from terrorism. In this case, Obama has called for more protection of privacy while acknowledging that the intelligence-gathering activities of the NSA should not be overly constrained. ${ }^{8}$ Trying to find a consensus on the balance between conflicting privacy and security rights that most people will accept illustrates Obama's principled pluralism on this issue.

\subsection{CONSTITUTIONALISM}

For Rawls (2005, 227-30), “constitutional essentials” deal with fundamental principles about governmental structures (like the separation of powers), the scope of majority rule, and the protections of the rule of law. In Martin's (2014, 284-85) interpretation of Rawls, the constitutional consensus does not require agreement on the particulars of the American Constitution, but rather evolving broad agreements regarding rights, practices, and procedures. Obama incorporated such understandings when he wrote appreciatively of "Our Con-

8. See "Liberty and Security in a Changing World," at www.whitehouse.gov/sites/default /files/docs/2013-12-12_rg_final_report.pdf. 
stitution" - not necessarily in its particulars or as interpreted by "Constitutional fundamentalists," "strict constructivists," or "originalists," but rather as providing "elaborate machinery ... designed to force us into a conversation, a 'deliberative democracy' in which all citizens are required to engage in a process of testing their ideas against an external reality, persuading others of their point of view, and building shifting alliances of consent" (2006, 92). Obama reads the Constitution as forcing upon Americans the processes of pluralist democracy, where diverse groups must take into account the interests and principles of others and where "we must test out our ideals, vision, and values against the realities of common life, so that over time they may be refined, discarded, or replaced by new ideals, sharper visions, deeper values" (94-95).

For Obama, constitutionalism goes beyond what is provided in the original Constitution and various amendments to it. Much of his discussion on constitutionalism in Audacity is concerned with the practice of filibusters, which is not a part of the Constitution. He objected to Republican threats in 2005 to employ "the nuclear option" of ending 200 years of Senate practices regarding the use of filibusters and the rules of debate, as "changing the rules in the middle of the game" (Obama 2006, 82). Thus, it may seem unprincipled that when changing balances of power in the Senate prompted Democrats to reduce the use of the filibusters in October 2013, Obama supported these changes in the rules. However, Obama can claim that he was acting within Rawls's understanding of constitutional consensus: "once settled it is vital that the structure (and procedures) of government be changed only as experience shows it to be required by political justice or the common good, and not be prompted by the political advantage of one party or group that at the moment has the upper hand" (Rawls 2005, 228). Obama supported only limited changes in rules regarding the filibuster. His claim was that effective governance was thwarted when senatorial Republicans used or threatened to use the filibuster to delay appointments of well-qualified administrators of congressionally authorized programs and of lower-level judges needed to fill court vacancies and deliver timely legal justice. It was these threats to "justice and the common good" that justified limited rule changes. Obama did not seek to limit the use of filibusters in the areas of appointments to the Supreme Court or in the passage of major legislation.

\subsection{BASIC SOCIAL STRUCTURES}

While Rawls, Klosko, and Martin all stress the importance of consensus on questions of "the basic social structures" of a pluralist society, their writings are less than clear about what these structures ought to be and how important each structure should be in organizing the activities of the citizens within 
America's various polities. Perhaps the following principles about structures can be regarded as being, or potentially being, part of the pluralist consensus.

First, economic markets, governments, voluntary associations, families, and cultural values are all important structures for organizing and coordinating the activities of citizens in community life. Second, the roles of each of these structures must be limited and balanced to avoid capitalist, governmental, theocratic, cultural, and other forms of domination; having countervailing structures is an important American principle. Third, governments are nevertheless the sovereign structures of American society (Walzer 1983, 281-84). While their powers must be limited, governments are the final court of appeals in resolving community conflicts, because-unlike economic actors, voluntary associations, families, and cultural norms-democratic governments have been authorized by constitutions to make certain rulings and because governmental officials have been empowered by (federal and state) constitutions and democratic processes to be the ultimate "referees" or "umpires" that resolve community issues.

During the past several decades, conservatives have stressed that the federal government has assumed too large a role in American society and have thus sought to limit its role and enhance those of free markets, churches, families, and traditional cultural values. Liberal Democrats have sought to reverse conservative advances in these areas and rebalance American social structures in ways that reflect their partisan principles that stronger governmental authority is needed to curtail various corporate abuses of power, that domestic violence must be subject to police intervention, that traditional culture values must be balanced with greater appreciation of multiculturalism, and that labor unions need to regain a greater role in civil society. Obama has supported many liberal initiatives in these areas, but he has always done so in ways consistent with the pluralist structural principles listed here. For example, Obama supported the creation of a new consumer protection agency and imposing greater restrictions on proprietary banking-but these restrictions were too narrowly framed to be regarded as radical structural changes in the political economy. ${ }^{9}$ Nothing in either Obama's rhetoric or his policy proposals suggests that he seeks to diminish significantly the role of economic markets and capitalist practices in structuring America.

Obama has supported legislation to strengthen those associations in civil society that have tended to support liberal ideals (especially labor unions), but he has avoided any initiatives that might undermine those (religious and commercial) associations that support conservative causes. He has also given

9. See Obama's remarks at www.whitehouse.gov/the-press-office/remarks-president-signing -dodd-frank-wall-street-reform-and-consumer-protection-act. 
voice to multicultural values while simultaneously supporting many traditional values, such as the "conservative notion of self-help." ${ }^{10}$ As these examples suggest, Obama's structural principles are pluralistic; rather than diminishing the role of any social structures or any (reasonable) cultural values, he has sought to affirm the importance of them all. Any structures that embed Americans more deeply into community life are useful correctives to the overly individualistic, indeed liberal, tendencies in American culture. Given the importance of individualism within American culture, such a stance may seem to be at odds with American consensual beliefs. But as Walzer (1990) reminds us, Americans have often pursued more communitarian principles in response to the excesses of liberal individualism, and as Eisenberg (1995) points out, pluralism has the capacity to reconcile liberal and communitarian ideals. Obama can be seen as merely seeking communitarian corrections to American society by strengthening its public and social structures in ways that remind the American people that "we are all in this together."

\subsection{DISTRIBUTIVE JUSTICE}

In A Theory of Justice, Rawls defended egalitarian and redistributive principles of justice (1999b, 53). However, philosophical objections from libertarians and widespread public support for market-based distributions that reflect differences in merit and contributions may be among the reasons that Rawls backed away from a strong interpretation of these principles. "Though a social minimum providing for the basic needs of all citizens is also an essential, what I have called the 'difference principle' is more demanding and is not" (Rawls 2005, 228-29). Pluralism provides principles of justice that can clarify Rawls evolving views, and Obama has supported these principles.

Pluralists endorse market justice: people should reap unequal rewards for their unequal merit and contributions within a free-market economy having rules that are fair and equally applicable to all. Pluralists also endorse social justice. This means initially that all people should have equal access to some public goods and services, such as public schools. Additionally, it recognizes that people have diverse disadvantages that cannot be overcome by providing equal services or equal minimal incomes for all. Accordingly, Rawls's principle calling for "social minimums" cannot be understood as seeking to provide all citizens with similar welfare checks. As emphasized by Nussbaum's capabilities approach, public assistance must come in many unequal forms that are

10. See Obama's speech “A More Perfect Union,” given in Philadelphia on March 18, 2008, at http://obamaspeeches.com/E05-Barack-Obama-A-More-Perfect-Union-the-Race -Speech-Philadelphia-PA-March-18-2008.htm. 
sensitive to the particular needs of those who are disadvantaged in various ways. Whether various public provisions are equal or unequal, social justice relieves recipients from paying market prices for these goods; taxes and other governmental revenues cover the costs. Pluralists understand the tensions between market and social justice and believe that these tensions are generally resolved in practice by adopting policies that enhance fair equal opportunity and that increase the progressivity of taxes.

After several decades of retrenchment of the welfare state by Republicans, who view poverty as largely an individual problem arising from personal failures, Obama was widely regarded during his first campaign for the presidency as a supporter of social justice, who would increase governmental programs to aid the disadvantaged. As president, he has expressed his liberal belief that many afflictions limiting the opportunities of the disadvantaged are not of their own making but arise from circumstances over which they have little control, ${ }^{11}$ and he believes that the American public, especially the rich, should provide greater public assistance to those in need. Such orientations can be seen in several of Obama's initiatives as president-most famously in those elements of the Affordable Care Act, upheld by the Supreme Court on June 24, 2015, in King v. Burwell, that provide public subsidies (of varying amounts) for those unable to afford health insurance.

There is extensive evidence that inequalities in income and wealth are increasing. In the most well-known recent work on this topic, Thomas Piketty (2014) emphasizes that these are not due simply to unequal contributions in the market or a reflection of merit as assessed by the quantity or quality of labor that individuals contribute to the production and availability of social goods. Piketty claims that increasing concentrations of wealth result from normal economic processes that provide returns on wealth that are greater than the rate of economic growth. The biggest gains in income and wealth in the United States in the past four decades have been received by corporate managers and those in the financial sector whose contributions and merit are difficult to measure, but who have benefitted from changing corporate processes and governmental regulations (330-33). The concentrations of wealth generated by such economic and political forces increasingly make inherited wealth a key component of income, which challenges the notion that economic inequalities are due to contribution and merit. Such concentrations of economic resources undermine the consensual ideal of real equal opportunity. Those with inherited wealth have far more opportunities than others to ac-

11. For a good illustration of such views by Obama, see his remarks on Trayvon Martin, at www.youtube.com/watch?v=MHBdZWbncXI (July 19, 2013). 
quire those human and material resources that are the keys to economic success in the marketplace.

On several occasions Obama has bemoaned America's widening inequalities in income and wealth, ${ }^{12}$ but he has yet to come up with an extensive set of policy initiatives to address the matter. For Obama, addressing inequality seems to involve the related goals of reducing unemployment and poverty, increasing opportunities for the poor (especially children raised in poverty), and having more governmental spending in such areas as early childhood and junior college education that are available to people having various disadvantages rather than to only those who can afford them. If these, rather than redistribution of income and wealth from the rich to the poor, are his real social justice goals, Obama is less the egalitarian liberal than a pluralist, having principles that are widely shared. As a pluralist, Obama seems more interested in providing "floors" (various forms of public assistance to support the poor and middle class) than establishing "ceilings" (that take away from the rich their capacity to acquire wealth and to bequeath it to their children).

Reducing inequality would require much more progressive taxes. According to Piketty, "the progressive tax is a relatively liberal method for reducing inequality, in the sense that free competition and private property are respected. ... The progressive tax thus represents an ideal compromise between social justice and individual freedom" $(2014,505)$.

On January 2, 2013, Obama signed a budget deal that added some progressivity to the tax code, raising from $35 \%$ to $39.6 \%$ the income tax rate on those earning over $\$ 388,500$ annually. Such an increase was less than that sought by liberals, and it fell short of Obama's call for following "the Buffet rule ... asking a billionaire to pay at least as much (percentage-wise) as his secretary in taxes." ${ }^{13}$ Perhaps he still hopes to increase the progressivity of the American tax code, but his pluralist perspective surely informs him that seeking such reforms must be tempered by the need to compromise with more conservative members of Congress.

\section{OBAMA'S PHILOSOPHICAL ASSUMPTIONS}

Underlying the sorts of political principles discussed above are various philosophical assumptions. Philosophical assumptions involve ontological, sociological, anthropological, and epistemological ideas that are beyond inter-

12. See "Remarks by the President on the Economy," delivered on December 6, 2011, at www.whitehouse.gov/the-press-office/2011/12/06/remarks-president-economy-owawatomie -kansas.

13. See Obama's State of the Union address delivered on January 24, 2012, at www .whitehouse.gov/state-of-the-union-2012. 
subjective verification. The universe, societies, humanity, and knowledge have many dimensions that make their characterization extraordinarily complex, but partisans typically assume that specific aspects of these foundations of political principles are especially important. God is at the center of the universe for religious fundamentalists. Societies are divided by class for Marxists. Humans are self-interested for classical liberals. Tradition provides the basis for political knowledge for cultural conservatives.

Pluralists avoid assumptions about the essences of things that are often the subjects of philosophical and ideological debate. Ask Americans with pluralist sensibilities to choose among a variety of religious, moral, and ideological assumptions about the nature of the universe, society, humanity, or knowledge, and they will normally reply that many of these ideas have some merit. This may reflect a lack of depth in American thinking, but perhaps it also represents what is most admirable about American political thought. Richard Rorty $(1998,15-38)$ has argued that what is inspiring in America is our refusal to constrain our politics by getting bogged down in metaphysical concepts and choices. Unlike Europeans, Americans do not seek a culture built on particular philosophical assumptions or ideational strands. Rather, we pursue a new and better culture that "will be a tapestry in which more strands have been woven together" (25). Obama provided similar imagery when he claimed in his first inaugural address that "our patchwork heritage is a strength, not a weakness."

This American attitude about de-emphasizing and indeed avoiding narrow philosophical assumptions is at the core of Rawls's project, in which he proposed not only doing away with thick or strong philosophical assumptions but also avoiding all philosophical assumptions. But in this he may have gone further than what is required for consensus in a diverse society. If the purpose of consensual ideals is to provide the bases for public political justification, then a large variety of philosophical assumptions drawn from many comprehensive doctrines might be assessable to most citizens and acceptable to many.

Convergence on strong philosophical assumptions seems impossible. But perhaps philosophical assumptions can be framed more thinly, at an intermediate level of abstraction that can be widely understood and command the respect of people committed to competing comprehensive doctrines. Obama has articulated or at least implied such philosophical assumptions.

\subsection{ONTOLOGY}

The most basic and perhaps least controversial assumption of pluralism is that we live in William James's "pluriverse"-a world of multiple and competing values (Ferguson 2007). Both Rawls and Obama (2006, 43-69) have em- 
phasized this assumption and have claimed that no single value is an absolute or supreme. Political life consists of choosing which values to pursue and setting priorities among them. This leads immediately to a second pluralist ontological assumption: that what happens here on earth or in America depends on our individual and collective choices about which values we wish to pursue. A third pluralist ontological assumption is that there is a certain attractiveness and plausibility in the ontological assumptions that are central to competing comprehensive doctrines. Such assumptions cannot be dismissed out of hand, but they should be given weaker interpretations than religions, moral philosophies, and political ideologies often assert (White 2000).

When those holding religious doctrines proclaim that God is ultimate reality and the ultimate force of what happens on earth, pluralists need not reject God's existence, but they can claim that the Divine Will does not completely determine what happens on earth. Pluralists can accept and applaud those who seek God but can point out that not everyone has found Him. Pluralists can accept weak ontological assumptions about God's existence and moral attractions (Rawls 2009), but they think that strong assumptions that we must obey God's Will are to be resisted both because God's Will is mysterious and because claims to know God's Will are too authoritarian to be acceptable as the basis of a pluralist democracy.

Populists claim that it is not God's Will that must be reflected in our political choices but the will of the people. Pluralists reject this strong ontological assumption for the same reasons they reject strong assumptions about God: the will of the people is often mysterious, and those who proclaim to know it often become authoritarians who quell dissent (Riker 1982, 238-49). Still, populist assumptions have some attractions in a democratic society, and a thinner version of populist assumptions can be accepted: public preferences must be respected, and political decisions should ordinarily not engender widespread public opposition.

Neoliberals and libertarians have often claimed that our policies must conform to the natural laws of economics: economic growth and prosperity, as measured by aggregate national income or wealth, are the keys to the realization of a broad array of values, and certain economic policies must inevitably and invariably be implemented to ensure prosperity (Steger 2009, 68-75). Pluralists reject such strong ontological assumptions, both because the laws of economic growth are disputed and because we can choose to pursue other political values (like economic equality and ecological sustainability) even if that means lesser economic growth.

Liberals have somewhat thicker ontological views than pluralists, as they assume that history will be progressive. Like Hegel, liberals believe that deficient ideals will be replaced by better ones, and that the accumulation of 
knowledge and moral understandings means that decay in the quality of life reflects merely temporary misguided applications of evolving ideals, but the most important and valid ideas can never be lost. Thus, as Francis Fukuyama (1992) has argued, the fundamental values of liberalism (individualism, freedom, equality, security, opportunity, and prosperity) and the basic social structures of liberalism (democracy and capitalism) are the ultimate political guides for the good life for all humans. Any misguided political actions that curtail the realization of these ideals will be detected by evolving human intelligence, and corrections will be made that reestablish progress toward the universal realization of liberal goals.

Pluralists are not so sure of these liberal assumptions. First, they believe that the values that liberals pursue can be too narrow, as pluralists can also appreciate socialist longings for more social solidarity and conservative longings for more respect for authority. Second, pluralists recognize that some people and cultures reject the values of liberalism (or other partisan perspectives that accept pluralist constraints). Pluralists think that it is possible that history could again be shaped by ontological assumptions that they find flawed as political guides, as political communities could submit to some fundamentalist articulation of God's or Allah's Will, to populist claims that the will of the majority must prevail, to some Marxist conception that economic forces will inevitably lead to an ideal communist society, or to the (neoliberal) globalist claim that "there is no alternative" but to submit to the laws of capitalist economics. Pluralists may seek to realize liberal values, but they are unlikely to assume that progress toward liberal ideals is inevitable; rather, they will see such progress as contingent. It can only be hoped for and pursued energetically. When put this way, it seems clear that Obama is more the pluralist than the liberal. His writings, speeches, and policy initiatives all exhibit an optimism that progress toward the fuller realization of liberal values is possible, but many obstacles-including our fears, cynicism, and hypocrisy—must be overcome (Obama 2006, 43-69).

\subsection{SOCIOLOGY}

Pluralists accept similar weak assumptions about the nature of society. First, they doubt that all societies share some essential characteristics, instead believing that existing societal characteristics are contextual. Second, they reject the ideas that societies must be homogeneous or that the individuals and groups that are part of society must be made subordinate to the collectivity. Third, they believe that all societies are composed of diverse individuals and groups having a mix of common and competing interests and values. Fourth, they will see some merit in various assumptions about how societies can be composed in 
order to coordinate the activities of diverse individuals and groups in a fair and effective manner.

Pluralists will thus be receptive to various assumptions about the nature of society. They can see merit in traditional views that societies are like orchestras, in that their various sections need effective leaders to conduct them and produce social harmony. They can see merit in the libertarian view that societies are marketplaces, where individuals are free to pursue their own interests, as long as the rules of the marketplace are fair. They can see merit in liberal conceptions that societies are held together by various social contracts.

Pluralists reject the Marxist assumption that societies are essentially class divided and instead will accept the more liberal and pluralist view that societies often contain a variety of social divisions defined by class, race, gender, and so forth. However, liberals seem somewhat more judgmental than pluralists about the "good guys" and the "bad guys" along these lines of cleavage. To the thinner assumption of pluralists that society has many social divisions, contemporary liberals tend to make thicker assumptions that one side of these divisions dominates, oppresses, exploits, and marginalizes the other. While there is little in the scholarly writings of liberalism to justify such judgments, liberal politicians, activists, and commentators in America-drawing from more radical left traditions-often claim that minorities are dominated by white majorities, that the poor are oppressed by the rich, that Wall Street is favored over Main Street, and so forth. The pluralist recognizes these social divisions but holds open the question whether the observed inequalities are justified. Pluralists are wary of the tendency of the left to stigmatize the successful, to invoke public sentiments against them for political gain.

While Obama has been willing to declare some practices as corrupt and to insist on measures to help the exploited and dominated, he has been reluctant to make grand generalizations criticizing such liberal enemies as "Wall Street," "corporate America," "big pharmacy," and that old standby "the militaryindustrial complex." For Obama, there are many actors in these sectors of society that are doing important tasks for the polity; their legitimate interests and ideals must be understood, and their real contributions must be acknowledged. As Obama pointed out in his "Remarks on Economic Mobility" on December 4, 2013, "We admire folks who start new businesses, create jobs, and invent products that enrich our lives. And we expect them to be rewarded handsomely for it." 14

This pluralist emphasis on social differences, rather than a more left-wing emphasis on denigrating those atop various social hierarchies, has been par-

14. See "Remarks by the President on Economic Mobility," delivered on December 4, 2013, at www.whitehouse.gov/the-press-office/2013/12/04/remarks-president-economic-mobility. 
ticularly evident in Obama's assumptions about race. Despite his advocacy for African Americans, Obama has downplayed racial grievances that demand white sacrifices and has avoided angry condemnations of white discrimination and indifference to the restricted opportunities of blacks, as asserted by such old-style civil rights leaders as Jesse Jackson and Al Sharpton. He chastised his own minister, Jeremiah Wright, for having "a profoundly distorted view of this country-a view that sees racism as endemic"-and for speaking "as if our country was static, as if no progress had been made."15

\subsection{ANTHROPOLOGY}

Turning to assumptions about human nature, perhaps the most basic pluralist idea is that people are basically equal and deserve equal respect, as Rawls has emphasized throughout his work and Obama has expressed throughout his presidency.

Pluralists also assume that people are neither inherently good nor evil. Or perhaps a better articulation of this claim is to accept the contention of Reinhold Niebuhr $(1944,10)$ that humans are both "children of darkness (who) are evil because they know no law beyond the self" and "children of light" who "seek to bring self-interest under the discipline of a more universal law and in harmony with a more universal good." In an interview with David Brooks, Obama declared his admiration for Reinhold Niebuhr's Christian realism (Siemers 2009, xi). Because liberals stress human goodness, they may forget the need for vigilance against the dark side that resides in each of us. This wariness of human limitations prompts Obama to be more cautious than his liberal friends would like. Left to their own inclinations, liberals may overreach in pursuing peace agreements with people who are more evil than liberals assume. While conservative "realists" often accuse Obama of naïve liberal beliefs, Obama's various foreign policy initiatives can be viewed as balancing or vacillating between seeing the goodness and evil in others. For Obama, liberal ideals about human nature justify efforts to try to reach out to those whom conservatives regard as evil, but his broader pluralist outlook makes him skeptical that others can be completely trusted.

Such recognition of diversity within and across people leads pluralists to find understandable and plausible a variety of strong assumptions provided by those committed to various comprehensive doctrines. For example, they recognize and indeed admire Rawls's claim in A Theory of Justice that having moral autonomy (the capacity to choose one's own life plan and moral principles) is a core motivation for people $(1999 \mathrm{~b}, 110)$. But pluralists also rec- 
ognize and admire the idea that people can be primarily motivated to be embedded in communities having religious and moral codes to which they are bound. Indeed, Political Liberalism can be viewed as Rawls's effort to accommodate the belief that many people in pluralist society have such motivations (Kymlicka 2002, 228-44). Obama has drawn on both the desire of humans for autonomy and their desire for social roots in justifying various policies. One of the virtues of Obamacare, Obama insists, is that it allows individuals many choices about health insurance and health care. One of the virtues of belonging to a church is that religion can strengthen morality and inculcate in people a greater sense of social purpose (Obama 2006, 214).

\subsection{EPISTEMOLOGY}

American pluralists also have weak but robust assumptions about the existence of "truth" in political life and how we can best approach political knowledge. Rorty $(1998,17)$ provides a forceful statement of the most basic epistemological belief of American pluralists: "a refusal to believe in the existence of Truth, in the sense of something not made by human hands, something that has authority over human beings." Americans "will take nothing as authoritative save free consensus between as diverse a variety of citizens as can possibly be produced" (30). This means that pluralists will not simply accept as truth the proclamations made by any kind of authorities, their interpretations of such "sacred" texts as the Bible and the Constitution, or the arguments provided in such canonical works as Adam Smith's Wealth of Nations or Rawls's A Theory of Justice. ${ }^{16}$

But in search of as much consensus on political truths as possible, in search of objectivity understood as intersubjective agreement among citizens, pluralists draw on various epistemologies. They may employ intuitions, proclaiming as conservatives do that there is within all people some common moral intuitions on which we can draw (Haidt 2012). They may employ the sort of deductive reasoning that has been used by liberals to seek agreement on the contents of various social contracts. Pluralists will also use a wide array of scientific methods to collect facts and generalize from them. Natural scientists accumulate evidence about such processes as global warming to get people to understand what Al Gore called "an inconvenient truth." Social scientists accumulate evi-

16. As Klosko $(2000,105-15)$ suggests, perhaps the greatest difficulty for pluralism is not its ability to accommodate fundamentalists, but that fundamentalists may be unwilling to accept pluralism. Fundamentalists (religious or otherwise) have had cognitive styles that resist any other source of justification than their own faith. But pluralists can take comfort in research showing that increasing encounters between fundamentalists and the rest of society have reduced such narrow-mindedness (Putnam and Campbell 2010, 541-50). 
dence about such economic, social, and political processes as capitalism's tendencies to lead to the concentration of wealth (Piketty 2014). While natural science and social science are often committed to positivist epistemologies that simply describe and explain our world, other scientific methods may be employed that add values to facts when making knowledge claims. Pluralists are open to and indeed seek utilitarian claims that the good consequences of a policy outweigh the bad for most effected people. Knowing through scientific investigation the consequences of policy alternatives can help greatly in reaching consensual moral judgments about which option is "for the greater good." Another scientific epistemology that pluralists use-indeed emphasize-is pragmatism.

It is widely regarded that Obama is a pragmatist, indeed, that his pragmatism leads him to compromise his liberal principles (see, e.g., Kloppenberg 2011). The problem with such a diagnosis is that no epistemology is more central to liberalism than pragmatism. Contemporary liberalism emerged out of an older classical liberalism when liberals recognized the limitations of logical deductions, utilitarianism, and intuitionism, as providing firm access to political truths. During the twentieth century, liberals became pragmatic in two senses. First, they recognized that there is no absolute truth about the good life, the good society, and good government to be pursued, but only compelling problems to be surmounted. Philosophical pragmatism has provided an experimental approach to achieving knowledge about effective means to combat totalitarian enemies on the world stage, to lift the economy out of depressions and recessions, to address discriminatory practices, and so forth. Second, liberals recognized that policy experiments on behalf of these quests would always be resisted, given the diverse views of powerful actors within modern pluralist societies; thus, putting together a coalition having sufficient power resources to undertake social experiments requires accommodating diverse interests. By recognizing such needs, Obama has been a liberal and philosophical pragmatist. But his epistemological assumptions run deeper and more broadly.

Pragmatism is an epistemological approach that might be effective at the level of policy making. It is an approach that brings together the expertise of various policy networks and gets them to reach their best judgments about how to address social problems in ways that reconcile various goals. But it is not an approach that addresses satisfactorily the larger political culture. Citizens have difficulty following the complexities of various economic stimulus policies, the nuances of public health proposals, the sort of environmental regulations that could reduce global warming, or effective strategies for combating terrorism. The political opposition can easily manipulate public opinion. Conservative Republicans can label Obama's pragmatic reforms as liberal ex- 
tensions of governmental power in their lives, rather than as efforts to respond to consensual concerns.

To counter such manipulation, pragmatism must be supplemented by reasonable claims that pragmatic reforms reflect consensual ideals. If widespread agreement can be attained on a wide range of ideals that compose the American consensus, these ideals can be used to justify certain pragmatic experiments and to criticize and even "veto" others that clearly violate consensual norms. But if the objective is to justify or condemn various political decisions, minimizing disagreement may not be so important. Diverse reasonable justifications drawn from various doctrines and ideologies may all be useful in this task.

This leads to the most important epistemological issue: how can we attain intersubjective knowledge about what are our reasonable consensual ideals? As an alternative to "convergence," pluralists can construct a large "toolbox" that contains our common sensibilities. Perhaps a better metaphor is that "playlists" containing many ideals arranged according to answers provided to the enduring questions of politics might be developed. While this article has suggested some such ideals, the contents of our consensus must be socially constructed and affirmed. Proposals for inclusion on the pluralist playlist should not be based on complex philosophical speculations; they must pay attention to common experiences and shared beliefs. The ideals of principled pluralism must be framed in ways that appeal to common sense. This involves appealing less to what particular citizens have habitually come to see as "common sense" than to common sensibilities-the ideals that are intersubjectively accepted.

Much depends on how our social understandings are articulated. For example, the American welfare state is highly controversial, perhaps because overly thick principles have been articulated as being necessary to it. "Government must redistribute material resources from the rich to the poor," "ceilings must be placed on the resources owned and controlled by the rich," and "the poor have welfare rights" are examples of fairly thick principles that make programs to reduce poverty so controversial. A less controversial principle is that "government has a responsibility to provide financial support for the poor, the sick, the young, the elderly, and the physically, mentally, and emotionally disabled." ${ }^{17}$ Of course, this principle is fairly thin, but it is potent enough to guide the resolution of many specific issues that involve social

17. See Schumaker and Kelly (2013) for research suggesting that such a "floors" principle is more effective than related expressions of support for social justice in reaching decisions that increase public assistance to the disadvantaged. 
justice. Both Rawls and Obama seem to recognize that few people are so hardhearted as to deny this ideal as part of American common sense.

\section{CONCLUSIONS}

Principled pluralism proposes a broad array of political principles and philosophical assumptions that can be appreciated by people as part of the underlying ideas of the political cultures in which they reside. This proposal is consistent with Connolly's view that pluralism is not about narrowing our political beliefs, but rather about broadening our receptivity toward others and the diversity of their beliefs.

Principled pluralism is not an absolute or static public philosophy, even for those like Obama who articulate and generally follow its ideals. Sometimes Obama's pluralism has been trumped by his liberalism, well illustrated by his executive actions since the elections in November 2014 to shield undocumented immigrants from deportation, to enter into international agreements to curb global warming, and to open relations with Cuba. But another way of understanding these actions is to see Obama as trying to move the pluralist consensus in a liberal direction.

Many Americans remain fairly intolerant and reject some equal rights stressed by principled pluralism. Yet Obama has given voice to the hope that these and other principles can be more widely accepted and that there is a plausible path to achieving a broader consensus in support of these ideals in the not distant future. Fifty years ago, our consensus supporting equal rights for minorities and women was much less than it is now. Our consensus supporting equal rights for LGBTQs seems to be expanding rapidly. It may take some time for a consensus to emerge behind the right to heath care as embodied in Obamacare, but welfare programs such as Social Security, Medicare, and Medicaid now enjoy broad support—even if they are subject to the sort of revisions that Obama recognizes as a normal part of pluralist politics.

John Rawls would probably accept principled pluralism as a public philosophy aimed at providing accessible and understandable justifications for political processes, decisions, and programs that can often be acceptable to partisans-though perhaps reluctantly and with reservations. Principled pluralism seems consistent with Rawls's inclusive conception of the overlapping consensus.

It is too early to assess fully Obama's presidency, but his receptivity to those having various religious and moral doctrines and competing partisan outlooks, his efforts to justify his decisions and policies in terms of consensual understandings, and his efforts to move American political culture to a broader un- 
derstanding of its ideals must be appreciated. The argument here is that John Rawls would likely applaud Obama's efforts in these areas.

\section{REFERENCES}

Campbell, David, and Morton Schoolman. 2008. The New Pluralism: William Connolly and the New Global Condition. Durham, NC: Duke University Press.

Connolly, William. 2005. Pluralism. Durham, NC: Duke University Press.

Dahl, Robert. 1961. Who Governs? New Haven, CT: Yale University Press.

. 1967. Pluralist Democracy in the United States. Chicago: Rand McNally.

Domhoff, G. William. 1978. Who Really Rules? New Brunswick, NJ: Transaction.

Eisenberg, Avigail. 1995. Reconstructing Political Pluralism. Albany, NY: SUNY Press.

Ferguson, Kennan. 2007. William James: Politics in the Pluriverse. London: Rowman $\&$ Littlefield.

Fukuyama, Francis. 1992. The End of History and the Last Man. New York: Avon.

Gutmann, Amy, and Dennis Thompson, 2004. Why Deliberative Democracy? Princeton, NJ: Princeton University Press.

Haidt. Jonathan. 2012. The Righteous Mind. New York: Vintage.

Hartz, Louis. 1955. The Liberal Tradition in America. New York: Harcourt, Brace.

Huntington, Samuel. 2004. Who Are We? New York: Simon \& Schuster.

Jacoby, William. 2014. "Is There a Culture War? Conflicting Value Structures in American Public Opinion." American Political Science Review 108 (4): 754-71.

Kloppenberg, James. 2011. Reading Obama. Princeton, NJ: Princeton University Press.

Klosko, George. 2000. Democratic Procedures and Liberal Consensus. New York: Oxford University Press.

Kymlicka, Will. 2002. Contemporary Political Philosophy. 2nd ed. New York: Oxford University Press.

Lowi, Theodore. 1979. The End of Liberalism. 2nd ed. New York: Norton.

Martin, Rex. 2014. "Overlapping Consensus." In A Companion to Rawls, ed. J. Mandle and D. A. Reidy. New York: Wiley.

McClosky, Herbert, and John Zaller. 1984. The American Ethos. Cambridge, MA: Harvard University Press.

Milkis, Sidney, Jesse Rhodes, and Emily Charnock. 2012. "What Happened to Postpartisanship? Barack Obama and the New American Party System." Perspectives on Politics 10 (1): 57-76.

Niebuhr, Reinhold. 1944. The Children of Light and the Children of Darkness. New York: Scribner's.

Nozick, Robert. 1974. Anarchy, State, and Utopia. New York: Basic.

Nussbaum, Martha. 2011. Creating Capabilities. Cambridge, MA: Harvard University Press.

Obama, Barack. 2006. The Audacity of Hope. New York: Crown.

Pew Research Center for the People and Press. 2014. "Political Polarization in the American Public." www.people-press.org.

Piketty, Thomas. 2014. Capital in the Twenty-First Century. Trans. Arthur Goldhammer. Cambridge, MA: Harvard University Press.

Putnam, Robert, and David Campbell. 2010. American Grace. New York: Simon \& Schuster. 
Rawls, John. 1999a. The Law of Peoples. Cambridge, MA: Harvard University Press. . 1999b. A Theory of Justice. Rev. ed. Cambridge, MA: Harvard University Press.

. 2005. Political Liberalism. Expanded ed. New York: Columbia University Press.

2009. A Brief Inquiry into the Meaning of Sin and Faith. Ed. Thomas Nagel. Cambridge, MA: Harvard University Press.

Riker, William. 1982. Liberalism against Populism. San Francisco: Freeman.

Rorty, Richard. 1998. Achieving Our Country. Cambridge, MA: Harvard University Press.

Sandel, Michael, 1996. Democracy's Discontents. Cambridge, MA: Harvard University Press.

Schlosberg, David. 2006. "The Pluralist Imagination.” In The Oxford Handbook of Political Theory, ed. John Dryzek, Bonnie Honig, and Anne Phillips. Oxford: Oxford University Press.

Schumaker, Paul. 1991. Critical Pluralism, Democratic Performance, and Community Power. Lawrence: University Press of Kansas. . 2008. From Ideologies to Public Philosophies. Oxford: Blackwell.

Schumaker, Paul, and Marisa Kelly. 2012. "Ethics Matter: The Morality and Justice Principles of Elected City Officials and Their Impact on Urban Issues.” Journal of Urban Affairs 34 (3): 231-53.

- 2013. "The Public Assistance Policies of Cities and the Justice Concerns of Elected Officials: The Centrality of the Floors Principle in Addressing Urban Poverty.” Policy Studies Journal 41 (1): 70-99.

Siemers, David. 2009. Presidents and Political Thought. Columbia: University of Missouri Press.

Smith, Rogers. 1997. Civic Ideals. New Haven, CT: Yale University Press.

Sniderman, Paul, Joseph Fletcher, Peter Russell, and Philip Tetlock. 1996. The Clash of Rights. New Haven, CT: Yale University Press.

Steger, Manfred. 2009. Globalisms. Lanham, MD: Rowman \& Littlefield.

Troy, Gil. 2012. Why Moderates Make the Best Presidents: George Washington to Barack Obama. 2nd ed. Lawrence: University Press of Kansas.

Walzer, Michael. 1983. Spheres of Justice. New York: Basic. 6-23.

White, Stephen. 2000. Sustaining Affirmation: The Strengths of Weak Ontology in Political Theory. Princeton, NJ: Princeton University Press.

Wolin, Sheldon. 1996. “The Liberal/Democratic Divide.” Political Theory 24 (1): 97119. 